\title{
SOME NOTES ON PARASITIC COPEPODA
}

\author{
By Robert Gurney, D.Sc.
}

(Text-figs. I-2)

\section{Developmental Stages in the Family LeRnaeopodidae}

The Lernaeopodidae are a highly specialized group of parasitic Copepoda presumably derived from a Caligoid stem, and some clue to their systematic position should be found in their development. Some stages are known in ten genera, but it is only in Achtheres, Salmincola, and Clavella that the whole, or nearly the whole, series of stages has been described. There is a very strong tendency to suppress the nauplius as a free stage though, when so suppressed, there may be moults corresponding to nauplius and metanauplius (Zandt, 1935). In some species there is certainly a free nauplius, but it probably moults into the copepodid in a very short time.

\begin{tabular}{ll} 
With free nauplius & \multicolumn{1}{c}{$\begin{array}{c}\text { Hatching as copepodid } \\
\text { Achtheres percarum Nordmann }\end{array}$} \\
& $\begin{array}{l}\text { Achtheres ambloplitis Kellicott (normally) } \\
\text { A.pseudobasanistes Zandt }\end{array}$ \\
Tracheliastes polycolpus Nordmann & [Syn. Basanistes coregoni Neresh.] \\
& Salmincola salmonea (L.) \\
Clavella uncinata (Müller) & Salmincola mattheyi Dedie \\
Charopinus dalmanni (Retz.) & Basanistes huchonis (Schrank) \\
Lernaeopoda galei Kröyer & Epibrachiella impudica (Nordmann)
\end{tabular}

I am indebted to Miss Lebour for larvae of Lernaeopoda galei hatched in the laboratory at Plymouth (Fig. I). In this species there is a nauplius, but it probably moults almost at once into the copepodid as all the appendages of the latter can be seen under the skin, and the head filament is quite distinct. One interesting feature of the nauplius is the possession of a mandibular appendage, since in all other species in which a nauplius has been described this appendage is absent altogether. In this species the appendage is, at the time of hatching, empty of tissues, but it is distinctly biramous, with three long setae on the exopod and two on the endopod. Both pairs of antennae have long setae, but they are not feathered, and it may well be that the nauplius does not actually swim.

The copepodid $(0.85 \mathrm{~mm}$. long) is slender, but of the usual form. The filament of attachment is fully formed, running backwards to the region of the maxillipede, where it is thrown into a double coil and then runs forwards again to just below the attachment disk. The mouth cone is large, consisting of a bifid lower lip and an upper lip quite distinct from it. The lower lip has a fringe of delicate hairs at the tip, but it is not easy to see, and it may actually be a finely striated membrane. The mandibles lie outside the cone and are simple 
stylets, but I have seen a minute papilla at the base which may be a vestige of an exopod. The maxillule has two lobes with two and three spines respectively. Maxilla and maxillipede are powerful prehensile organs, the former with a slender claw and the latter with a more massive curved claw, in this respect quite unlike Clavella and Epibrachiella, and more resembling Salmincola. Nothing is known about later stages.

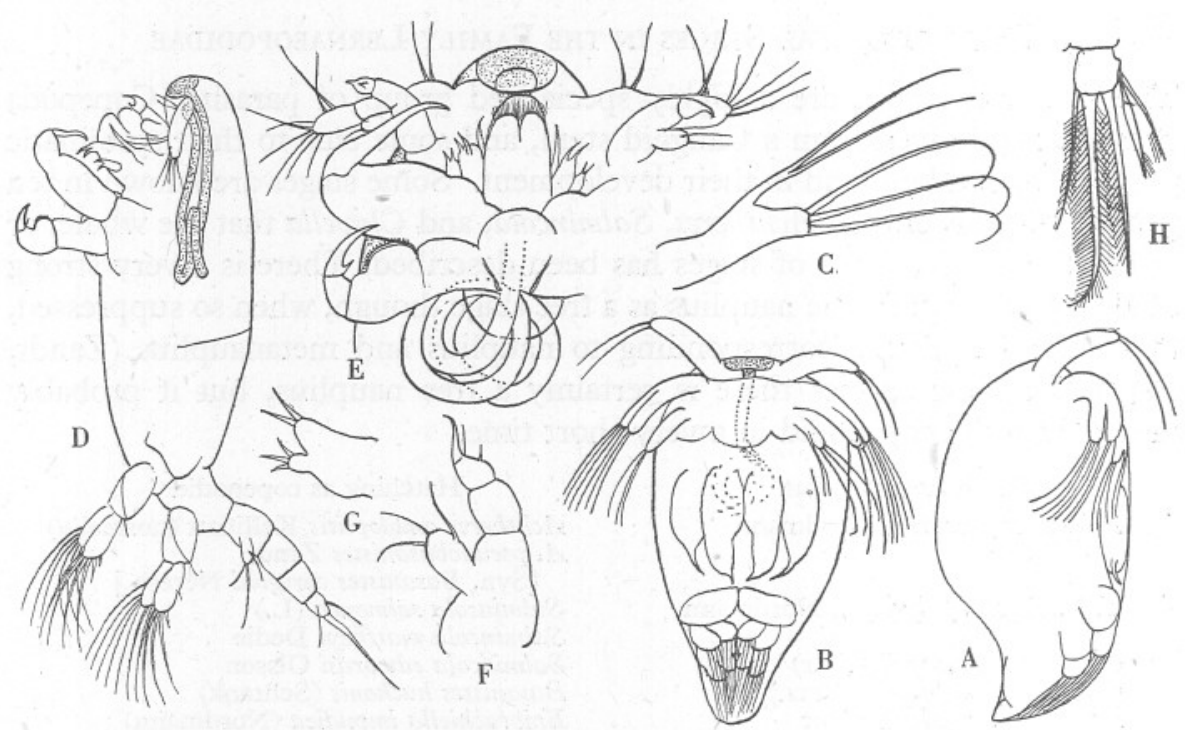

Fig. I. Lernaeopoda galei. A, B, nauplius; C, mandible of nauplius; D, copepodid; E, head region of copepodid, ventral view; $F$, antenna of copepodid; $G$, maxillule of copepodid; $\mathrm{H}$, left furcal ramus, ventral view.

There have been three recent papers dealing with the development of Lernaeopods (Zandt, 1935; Dedie, I940; Friend, 194I) and it is remarkable that there are apparently very great differences in the series of stages. According to Zandt there are no less than six moults, and seven stages in all, which is one more moult and stage than in the development of the free-swimming copepods. Throughout these moults no new appendages are acquired, and the animal remains throughout at the same developmental grade as copepodid I of normal free-swimming Copepoda.

In Table I the series of stages in four species are summarized, and it will be seen that there is a progressive shortening of development. In S. salmonea, according to Friend, there are only three moults, and the female has a stage during which she is attached to the host only by the grasping maxillipedes. In Clavella there appear to be not more than three moults, and it is possible that the female has a very brief period of freedom after loosing from the head filament and before attachment by the bulla or maxillary disc. 


\section{Table I. Developmental Stages in Four Lernaeopods}

\begin{tabular}{|c|c|c|c|c|}
\hline & $\begin{array}{l}\text { Achtheres pseudo- } \\
\text { basanistes Zandt }\end{array}$ & $\begin{array}{l}\text { Salmincola } \\
\text { mattheyi Dedie }\end{array}$ & $\begin{array}{l}\text { Salmincola } \\
\text { salmonea (L.) }\end{array}$ & $\begin{array}{c}\text { Clavella } \\
\text { uncinata Müller }\end{array}$ \\
\hline Observer: & Zandt, 1935 & Dedie, 1940 & Friend, I94I & Gurney, I934 \\
\hline Stage I & $\begin{array}{l}\text { Copepodid I: } \\
\text { free, later } \\
\text { attached by } \\
\text { head filament }\end{array}$ & $\begin{array}{l}\text { Copepodid I: } \\
\text { the same }\end{array}$ & $\begin{array}{l}\text { Copepodid } \mathrm{I} \text { : } \\
\text { the same }\end{array}$ & $\begin{array}{l}\text { Copepodid I: } \\
\text { the same }\end{array}$ \\
\hline II & $\begin{array}{l}\text { Copepodid 2: } \\
\text { attached by } \\
\text { head filament, } \\
\text { legs reduced }\end{array}$ & $\begin{array}{l}\text { Metamorphosed; } \\
\text { filament de- } \\
\text { tached from } \\
\text { head and grasped } \\
\text { by maxillae }\end{array}$ & $\begin{array}{l}\text { Filament de- } \\
\text { tached from } \\
\text { head and grasped } \\
\text { by maxillae }\end{array}$ & $\begin{array}{l}\text { Copepodid 2: } \\
\text { legs reduced, } \\
\text { attached by } \\
\text { head filament }\end{array}$ \\
\hline III & $\begin{array}{l}\text { Filament detached } \\
\text { from head and } \\
\text { grasped by } \\
\text { maxillae }\end{array}$ & Ditto & $\begin{array}{l}\text { Metamorphosed; } \\
\text { Ist stage female } \\
\text { free, clinging by } \\
\text { maxillipedes }\end{array}$ & $\begin{array}{l}\text { Metamorphosed; } \\
\text { attached by fila- } \\
\text { ment and skin } \\
\text { of copepodid }\end{array}$ \\
\hline IV & Ditto & Ditto & $\begin{array}{l}\text { 2nd stage female, } \\
\text { attached by } \\
\text { bulla }\end{array}$ & $\begin{array}{l}\text { Sexes distinct, } \\
\text { female attached } \\
\text { by bulla }\end{array}$ \\
\hline $\mathrm{V}$ & $\begin{array}{c}\text { Ditto } \\
\text { (Legs still traceable) }\end{array}$ & $\begin{array}{l}\text { Sexes distinct; } \\
\text { female fertilized, } \\
\text { still attached by } \\
\text { filament }\end{array}$ & - & - \\
\hline VI & $\begin{array}{l}\text { Approaching adult } \\
\text { form; sexes } \\
\text { distinct; still } \\
\text { fixed by filament }\end{array}$ & $\begin{array}{l}\text { Female attached } \\
\text { by bulla }\end{array}$ & - & - \\
\hline VII & $\begin{array}{l}\text { Male free, female } \\
\text { fixed by bulla. } \\
\text { No further moult }\end{array}$ & - & - & - \\
\hline
\end{tabular}

Leigh-Sharpe (1935) has recorded the occurrence of this species in the spring of 1934 on about $3 \%$ of the sprats caught at Hole's Hole in the river Tamar near Plymouth. On Io April of the same year I found the same percentage of infection on sprats from Hole's Hole, young herrings taken in the same place being entirely free from the parasite. Leigh-Sharpe does not give the actual date of his catch, but it is remarkable that, while his specimens were mature and bearing eggs, not one of mine was full-grown or bore eggs. In no instance was more than one parasite found on one fish. In one specimen a hole was seen in the eye, but no parasite emerging, and on dissection the chitinous remains of an adult specimen were found embedded in a cyst in the eyeball. Sproston \& Hartley (I94I) found a very much lower percentage of infection of sprats in the Tamar during 1935 and I936, namely $0.655 \%$ among 1376 fish taken throughout the year.

The youngest stage found corresponded to the free-swimming adult stage of Lernaeocera branchialis (L.), and was about $3 \mathrm{~mm}$. long, with a part of the abdomen projecting from the hole in the fish's eye, and the head embedded in 
the tissues at the back of the eye. It is to be presumed that the specimen figured (Fig. 2) is actually the earliest stage in which the fish is attacked. It would seem probable that it does not pierce the eyeball until the abdomen is

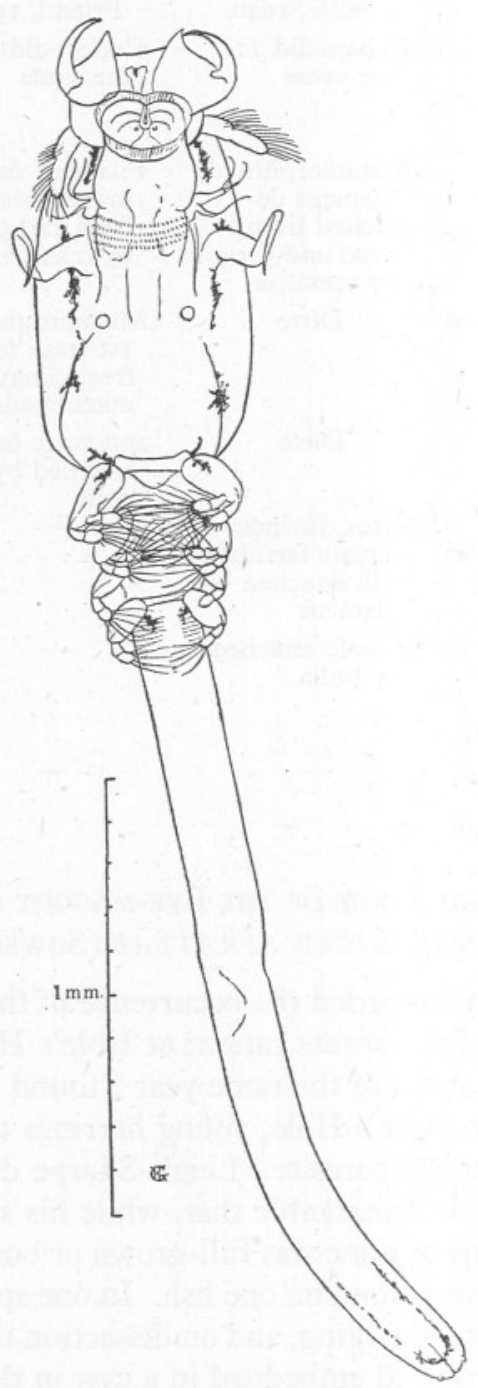

Fig. 2. Lernaeenicus sprattae Sowerby. Young specimen from eye of sprat.

long enough to project through the hole made while the head reaches to the back of the eye. The proportion of length of abdomen to cephalothorax is about the same as that in some specimens of $L$. branchialis still attached to the gill of a flounder. While the animal is sufficiently provided with organs of 
prehension, the circlets of spinules at the base of the mouth cone may also assist in fixation.

I have not found any earlier stages on the body, fins or gills of the sprat, but the number examined is very small and, in view of the rarity of the copepod, the possibility that the early stages are passed on some part of the same host cannot be excluded. I have found none on the gills of a flounder which bore large numbers of larvae of $L$. branchialis.

While it is easy to follow every stage of development on the sprat from the time of attachment to the eye, nothing is at present known about the copepodid stages.

\section{REFERENCES}

Dedie, O., I940. Étude de Salmincola mattheyi n.sp. Copépode parasite de l'OmbleChevalier (Salmo salvelinus). Rev. Suisse Zool., T. 47, pp. I-63.

FRIEND, G. F., I94I. The life-history and ecology of the salmon gill-maggot Salmincola salmonea. Trans. R. Soc. Edinb., Vol. 60, pp. 503-4I.

GuRney, R., I934. The development of certain parasitic Copepoda of the families Caligidae and Clavellidae. Proc. Zool. Soc. Lond., I934, pp. I78-2I7.

LeIgh-Sharpe, W. H., I935. Two Copepods (Lernaeenicus) parasitic on Clupea. Parasitology, Vol. 27, pp. 270-5.

Sproston, N. G. \& Hartley, P. H. T., I94I. The ecology of some parasitic copepods of gadoids and other fishes. Fourn. Mar. Biol. Assoc., Vol. 25, pp. 361-92.

ZANDT, F., I935. Achtheres pseudobasanistes n.n.syn. Basinistes coregoni (Neresheimer), Die postembryonale Entwicklung und geographische Verbreitung eines Lernaeopodiden. Zool. Fahrb. Fena (Anat.), Bd. 6o, pp. 289-344. 